\title{
STATUS AND PROGNOSIS FOR ALTERNATIVE ENGINE MATERIALS
}

\author{
Joseph R. Stephens and Michael V. Nathal \\ National Aeronautics and Space Administration \\ Lewis Research Center \\ Cleveland, Ohio 44135 USA
}

\begin{abstract}
The purpose of this paper is to review the current state of research and development of new materials for advanced aircraft engines. The advantages and disadvantages of intermetallic compounds and refractory metals as replacements for today's nickel-base alloys are discussed, along with some results of research directed at overcoming some of the problems which restrict their application. It is concluded that continuous fiber reinforced intermetallic matrix composites offer one of the best chances for success. However, major technical barriers still exist, especially in the development of suitable fibers, and introduction of these materials into aircraft engines is expected to take in excess of 5 to 10 years for most of these materials.
\end{abstract}

\section{Introduction}

Nickel-base and to some extent cobalt-base superalloys have been the primary materials in the hot zone of gas turbine engines since their commercialization. Although the properties of the superalloys continue to be improved via alloying, microstructural modifications, and innovative processing techniques, it is apparent that their maximum use temperature is rapidiy being approached. Because of the limitation imposed by the melting temperatures of the superalloys and the need for more efficient, higher performance aircraft engines, the DOD and NASA have undertaken joint as well as independent programs to extend the use temperature and reduce the weight of future military and commercial engines. The potential payoffs for the use of new materials with higher temperature capabilities and/or lower densities include reduced cooling requirements, reduced weight throughout the engine, and increased thermodynamic efficiencies which will lead to reduced fuel consumption. For example, if the light weight aluminide intermetallics can be utilized in the turbine, the weight reduction can be translated throughout the engine and supporting structure with accompanying payoffs in both engine performance and cost savings. This paper will present some of the materials now under investigation, discussing their potential and the key technical issues that need to be addressed, and then briefly summarize our best estimate of when these materials may see application in engines for future aircraft.

Superalloys 1988

Edited by S. Reichman, D.N. Duhl

G. Maurer, S. Antolovich and C. Lund

The Metallurgical Society, 1988 
The potential of intermetallic compounds as high temperature structural materials has been recognized for some time now, al though achievement of that potential has not been easy. Of the vast numbers of existing compounds, relatively few have been studied for use in structural applications. Table I lists some of these materials along with some of their advantages and disadvantages. In recent years the aluminides have received the most attention, as a result of their potential advantages of low density, high strength, and good environmental resistance. Although attempts to improve one property have frequently resulted in sacrifices of some of the benefits, significant progress has been made such that some aluminides should begin to see application within the next 5 years. For longer term application, a wide variety of other intermetallic compounds, including silicides, refractory metal aluminides, and beryllides, have also exhibited potential. The bulk of this discussion will be restricted to those aluminides which may be used within the next decade.

Table I. Some Potential Intermetallic Compounds

\begin{tabular}{|c|c|c|}
\hline Compound & Advantages & Disadvantages \\
\hline \multicolumn{3}{|c|}{ Near Term Application } \\
\hline $\begin{array}{l}\mathrm{Ni} 3 \mathrm{Al} \\
\mathrm{Ti} 3 \mathrm{Al} \\
\mathrm{TiAl} \\
\mathrm{FeAl} \\
\mathrm{NiAl}\end{array}$ & $\begin{array}{l}\text { Ductility } \\
\text { Density } \\
\text { Density } \\
\text { Ductility, oxidation } \\
\text { Melting point, oxidation }\end{array}$ & $\begin{array}{l}\text { Density, melting point } \\
\text { Oxidation } \\
\text { Ductility } \\
\text { Melting point, density } \\
\text { Ductility }\end{array}$ \\
\hline \multicolumn{3}{|c|}{$\begin{array}{l}\text { Far Term Application (Typical examples of the many potentia } \\
\text { compounds) }\end{array}$} \\
\hline $\begin{array}{l}\mathrm{Ti}_{5} \mathrm{Si}_{3} \\
\mathrm{Nb}_{5} \mathrm{Si}_{3} \\
\mathrm{Nb}_{3} \mathrm{Al} \\
\mathrm{NbAl} 3 \\
\mathrm{TiAl}_{3} \\
\mathrm{MoAl}_{2} \\
\mathrm{Nb}_{2} \mathrm{Be}_{17} \\
\mathrm{ZrBe} 13\end{array}$ & $\begin{array}{l}\text { Density } \\
\text { Melting point } \\
\text { Melting point } \\
\text { Melting point, density } \\
\text { Density } \\
\text { Melting point } \\
\text { Melting point } \\
\text { Melting point }\end{array}$ & $\begin{array}{l}\text { Ductility } \\
\text { Ductility, oxidation } \\
\text { Ductility, oxidation } \\
\text { Ductility, oxidation } \\
\text { Ductility } \\
\text { Ductility, oxidation } \\
\text { Ductility, oxidation } \\
\text { Ductility, oxidation }\end{array}$ \\
\hline
\end{tabular}

Figure 1 presents a summary of the density corrected yield strengths for various intermetallics and superalloys, which can serve as a starting point for rough comparisons. Because mechanical properties are sensitive to many microstructural and compositional variables, caution is required in interpreting this figure. Furthermore, short term monotonic strength is not sufficient for determining the suitability of a material for engine applications where life, environment, and cyclic conditions play critical roles.

NASA's program on intermetallics has focused primarily on the equiatomic aluminides $\mathrm{NiAl}$ and $\mathrm{FeAl}$. These two compounds possess the $\mathrm{B} 2$ (ordered $B C C$ ) crystal structure, and have densities around $6 \mathrm{gm} / \mathrm{cm}^{3}$. FeAl has a melting point of $1340{ }^{\circ} \mathrm{C}$ and therefore, has the most potential for intermediate temperature (i.e., below $1050^{\circ} \mathrm{C}$ ) applications. Iron rich 
( $\mathrm{Fe}-40$ at $\% \mathrm{Al}$ ) is one of the few aluminides with measurable low temperature ductility, about 3 to 5 percent elongation at room temperature (1). It can be processed by most conventional metal processing methods, such as induction melting and powder metallurgy techniques, extrusion, and hot and warm rolling. Alloying with $\mathrm{Zr}$ or $\mathrm{Hf}$ has been shown to improve strength up to about $700{ }^{\circ} \mathrm{C}$ while still maintaining ductility (2). Boron additions can have a small, but beneficial effect on the low temperature ductility of many FeAl alloys, where a change from intergranular to transgranular failure accompanies the increase in ductility $(1,2)$. The FeAl alloys have excellent cyclic oxidation resistance up to at least $1000{ }^{\circ} \mathrm{C}$ (3), and are not susceptible to intermediate temperature oxygen-induced embrittlement (2). However, their strength and creep resistance decrease quickly above $700^{\circ} \mathrm{C}$, and it is not clear that further significant improvements in high temperature strength can be achieved without sacrifice of some other property. Although the combination of these properties and inexpensive raw material cost make FeAl attractive as a replacement for stainless steels in aircraft engines, its potential for aeropropulsion systems seems limited. However, it still has attractive density, ductility, and oxidation resistance for use as a matrix for a composite which could possibly see applications up to as high as $1100{ }^{\circ} \mathrm{C}$.

NiAl has a much higher melting point, $1638^{\circ} \mathrm{C}$, and similar density to FeAl, and thus is more attractive for higher temperature service. NiAl has excellent cyclic oxidation resistance to at least $130{ }^{\circ} \mathrm{C}$, especially when alloyed with small additions of rare earth elements (4). Although some early work (5) reported room temperature ductility in polycrystalline NiAl, a more commonly observed behavior is a ductile to brittle transition temperature near 300 to $600{ }^{\circ} \mathrm{C}$, depending on composition, grain size, and processing (5-8). Single crystals have exhibited ductility (7), but even single crystals suffer from a low cleavage strength. Grain refinement, which is achieved by thermomechanical processing ( 9 ) or by rapid solidification (10), appears to give some improvement in low temperature ductility ( 8 ). Additionally, compressive creep testing of powder metallurgy processed materials (9) has shown that fine grains are stable and do not harm creep resistance to at least 70 percent of its melting point. Studies have shown that it is relatively easy to improve the creep resistance of $\mathrm{NiAl}$ to equal or exceed that of superalloys $(11,12)$, although achievement of ductility has remained more elusive. Strategies with the best chance for improving low temperature toughness appear to be macro-alloying in order to change the slip system from $\langle 100\rangle$ to $\langle 110\rangle$ type, or to reduce $\mathrm{Al}$ levels such that some $\mathrm{Ni}_{3} \mathrm{Al}$ is formed. Although these alloying changes decrease the density, creep, oxidation and melting point advantages, an appropriate balance of properties may still be achieved for certain lower temperature applications such as turbine disks.

$\mathrm{Ni}_{3} \mathrm{Al}$ has been studied extensively, primarily through the leadership of Oak Ridge National Laboratory (ORNL) (13). This compound has good low temperature ductility and good strength up to $800^{\circ} \mathrm{C}$, combined with good processability. However, sensitivity to an intermediate temperature oxygeninduced embrittlement has been observed. This problem has been reduced by alloying with about 8 at $\% \mathrm{Cr}$. However, the $\mathrm{Ni} \mathrm{z}_{\mathrm{Al}}$ based alloys with a balance of properties have only limited density and melting point advantages over superalloys, and do not appear to be able to offer large increases in engine performance.

$\mathrm{Ti}_{3} \mathrm{Al}$ and TiAl have been developed under Air Force sponsorship (14-16) over the last 15 years, for use at temperatures up to $1000{ }^{\circ} \mathrm{C}$. $\mathrm{Ti}_{3} \mathrm{Al}$ has a low density, $4.2 \mathrm{gm} / \mathrm{cm}^{3}$, which is sacrificed somewhat when $\mathrm{Nb}$ is added for ductility improvements. Oxidation resistance is lower than the $\mathrm{Ni}$ and $\mathrm{Fe}$ aluminides, and coatings will be necessary for applications above about 
$700{ }^{\circ} \mathrm{C}$. TiAl has an even lower density, $3.9 \mathrm{gm} / \mathrm{cm}^{3}$, and the potential for better environmental resistance and higher temperature capability, although ductility is lacking. Both $\mathrm{Ti}$ aluminides are also potential matrices for composites.

\section{Intermetallic and Metal Matrix Composites}

Intermetallic matrix composite (IMC) and metal matrix composite (MMC) materials are currently of extreme interest for future high temperature, high efficiency, high performance aircraft engines for both civil and military applications. NASA Lewis Research Center is currently investigating continuous fiber reinforced composites of $\mathrm{FeAl}$ and $\mathrm{NiAl}$ primarily under the NASA High Temperature Engine Materials Program (HITEMP) and $\mathrm{Ti}_{3} \mathrm{Al}+\mathrm{Nb}$ in the joint NASA-DOD program called NASP (National Aerospace Plane Program). In addition, many industrial organizations and universities under government contracts and grants are investigating the SiC reinforced $\mathrm{Ti}_{3} \mathrm{Al}$ and $\mathrm{TiAl}$ systems. ORNL has some effort underway on $S i C / N i 3 A l$.

By going the composite route the low density of the intermetallic compounds can be utilized to good advantage and if low density, high strength fibers are available, the low strength of the intermetallic matrices becomes less of an issue. Thus, the matrix can be optimized for other properties, most importantly ductility, oxidation resistance, and density. The influence of the fiber on strength properties of a composite has been discussed (19) for the use of SiC in aluminide matrices where the predicted strengthto-density for SiC reinforced aluminide composites was shown to be essentially independent of matrix strength. Thus, the low matrix strength typical of many of the aluminides at the higher temperatures can be overcome by the use of high strength fibers present at a volume fraction ranging from 30 to 50 percent. As an example, it was shown (20) that in a 40 vol \% W/Nb-1Zr composite (high strength fiber in a relative weak matrix), the matrix carries only about 3 percent of the load during high temperature creep testing. An example of the added strength properties achievable by a composite material is afforded by the comparison on a density corrected basis made in Fig. 2 where the properties of a $40 \mathrm{vol} \% \mathrm{SiC} / \mathrm{Ti}_{3} / \mathrm{Al}+\mathrm{Nb}$ composite are shown along with tensile properties of wrought nickel base and cobalt base alloys and the tensile strength of a single crystal superalloy, NASAIR 100. The strength advantage of the composite is evident in this comparison which provides the incentive for the research currently underway on these materials. Of course, there are many important problems that still must be solved, including transverse properties, creep, mechanical and thermal-mechanical fatigue, fabrication and joining, chemical compatibility between fiber and matrix, and differences in thermal expansion that would cause cracking during thermal cycling.

One of the major disadvantages of current composite systems under consideration is the chemical compatibility between fiber and matrix. This issue has been addressed (22) for the $\mathrm{SiC} / \mathrm{Ti}_{3} \mathrm{Al}+\mathrm{Nb}$ system and the results to date are summarized in $\mathrm{Fig}$. 3. The reaction is probably diffusion controlled and illustrates the extent of the fiber-matrix interaction that can take place upon exposing this composite to high temperatures. Based on these results it is evident that the properties of such a composite must be thoroughly explored as a function of use temperature and time of exposure.

A second major disadvantage is the thermal expansion mismatch between fiber and matrix. The commercially available fiber, Sic, that we have used for most investigations on the aluminide composites has a very low coefficient of thermal expansion (CTE), $5.5 \times 10^{-6}{ }^{\circ} \mathrm{C}^{-1}$ (23). In contrast, the aluminides have typically high CTE's ranging from $10 \times 10^{-6}{ }^{\circ} \mathrm{C}^{-1}$ for $\mathrm{Ti}_{3} \mathrm{Al}+\mathrm{Nb}$ (24), $14.5 \times 10^{-6}{ }^{\circ} \mathrm{C}^{-1}$ for NiAl (25), to as high as $20.9 \times 10^{-6}{ }^{\circ} \mathrm{C}^{-1}$ for $\mathrm{FeAl}$ 
(25). The effect that this difference in CTE's can have during thermal cycling is illustrated for the $\mathrm{SiClTi} 3 \mathrm{Al}+\mathrm{Nb}$ composite system (22) as shown in Fig. 4. Microcracks are noted to have developed after only three cycles of heating to $985^{\circ} \mathrm{C}$ and cooling to room temperature. In contrast, the CTE of $\mathrm{Al}_{2} \mathrm{O}_{3}$ is $9.0 \times 10^{-6}{ }^{\circ} \mathrm{C}^{-1}$ (26) which is in excellent agreement with that of $\mathrm{Ti}_{3} \mathrm{Al}+\mathrm{Nb}$. Thus, based on the criterion of matching CTE's, $\mathrm{Al}_{2} \mathrm{O}_{3}$ becomes a strong candidate as a reinforcement for this aluminide. Again, other factors such as chemical compatibility, lower strength, and availability compared to SiC must be weighed against this advantage of matching CTE which further illustrates the trade-offs that come into play when development of a composite system is being considered.

These initial results on the $\mathrm{SiC} / \mathrm{Ti}_{3} \mathrm{Al}+\mathrm{Nb}$ composite help to illustrate why we consider the development of compatible fibers to be a key issue that limits the application of light weight composites for future aircraft engines. To address this critical technology a potpourri of properties are desirable for future high temperature fibers which include: matching coefficient of thermal expansion and chemical compatibility with the matrix, low density, high modulus of elasticity, high melting temperature, high temperature strength, good oxidation resistance, spoolable, and capable of mass production. To develop a fiber with these properties will take a considerable amount of funding, innovative research, and time. Still another approach to address these issues is to coat existing fibers such as SiC or graphite with a thin layer of a "functionally gradient material" that will be chemically compatible with both fiber and matrix and will have an intermediate graded CTE which will help to solve the thermal cycling problem. Such an approach is underway by Japanese investigators (27) as well as by several investigators within the U.S.

Composite fabrication also may be a limiting factor in the application of the aluminide matrix composites due to fiber-matrix reaction during the high-temperature fabrication processing and also because of the inherent attraction for oxygen by the aluminides which may lead to contamination and increased brittleness of the matrix. Our approach has been to fabricate monotapes by one of several techniques including powder cloth, arc spray, and plasma spray. Subsequent composite consolidation is normally achieved by vacuum hot pressing or by hot isostatic pressing. The powder techniques are particularly susceptible to oxygen contamination and thus the search for other more controlled techniques is necessary. The importance of final composite consolidation must also be considered. The processing parameters of time, temperature, and pressure must be optimized to obtain the best compromise of sometimes divergent property requirements. If processing time is too short and temperatures and pressures too low, insufficient bonding between fiber and matrix will occur. Conversely, if time is too long and temperature and pressure are too high, excessive reaction between the fiber and matrix can occur. Both of these extremes will lead to inferior composite properties. A final step in the fabrication of composites is the necessity to join them to other components. These techniques will have to be developed to make composites viable materials for future applications. Paralleling these developments will be the necessity of developing adequate NDE techniques to inspect composites during the initial fabrication steps to final component fabrication and use.

So far we have only discussed the use of continuous fibers. Another approach that is underway is the use of particulates in the light weight matrices. An example of this concept is a study on $\mathrm{TiB}_{2}$ reinforced $\mathrm{NiAl}$ (28). The potential of strengthening $\mathrm{NiAl}$ with increasing volume percent of particulate is illustrated in Fig. 5 which provides a comparison with IN-601, TD-NiCr, and a single crystal superalloy, PWA-1480. The enhancement of strength was shown to be due to the effectiveness of the particles 
to interact with dislocations. For the matrix only a low dislocation density was observed after deformation. However, with the $\mathrm{TiB}_{2}$ present particulate-dislocation interactions were evident and a much higher dislocation density was observed.

\section{Refractory Metals}

The aluminides under consideration have a peak melting temperature near $1750^{\circ} \mathrm{C}$. To utilize metallic materials rather than turn to ceramics or ceramic composites the refractory metals have once again come under consideration. A lot of resources were expended on the refractory metals, especially niobium base alloys for aircraft and space shuttle applications in the 1960's and 1970's. Today's interest once more is in niobium base alloys with some interest in molybdenum base alloys. Oxidation still remains the Achilles heel for these materials. Recent results on Nb alloying (29) with the sole purpose of improving the oxidation resistance have been reported which demonstrated the feasibility of forming protective alumina scales by the selective oxidation of Al. Even with this approach, achieving an oxidation resistant alloy for use at temperatures above $1350{ }^{\circ} \mathrm{C}$ for long periods of time remains a formidable task.

\section{The Future for Aircraft Engine Materials}

What is our prognosis for the incorporation of these experimental materials in flight hardware? To help us address this question, the developmental history of MA-6000 (30) is used as an example. The technology transfer from the initial focused research to the estimated time of actual flight hardware is seen in Fig. 6 to be in excess of 16 years and at a cost of 15 to 20 million dollars. It should be noted that some of the pitfalls in trying to make these types of predictions will be exemplified by a paper presented at this conference where one of the first intended uses of MA-6000 has been postponed due to unexpected technical shortfalls of the material (31). This time frame of 15 plus years has been shown to be reasonable for the introduction of other materials such as single crystal superalloys into gas turbine engines and as mentioned earlier in this paper the research on the titanium aluminides was initiated about 15 years ago and these materials still await introduction into engine use. In contrast, materials such as thermal barrier coatings were transferred from research to flight applications in about 7 years (30). Our estimate for the various materials presented herein are shown in Fig. 7. At best, the $\mathrm{Ti}$ base aluminides are probably 5 years away from engine flight hardware. In looking at Fig. 7 , it should also be pointed out that new engines produce more specific thrust and thus low density materials can be very significant in terms of the overall engine even at small weight percents. The remaining intermetallics, composites, and refractory alloys are realistically in the 10 year plus time frame. Any prediction of course, depends on the funding that is sustained over a period of 5 to 15 years in order for the materials and structures technologists along with design engineers to be able to bring these materials to a point of readiness. In addition, the manufacturing technology will have to be developed and production facilities put in place.

In conclusion, we believe the payoffs of fuel efficiency, increased performance, and reduced operating costs make the current research on these advanced materials worthwhile, and will lead to exciting results which we and others will hopefully report at future Seven Springs Symposia. 


\section{References}

1. M.A. Crimp, K.M. Vedula, and D.J. Gaydosh: in High Temperature Ordered Intermetallic Alloys II, MRS Proc. Vol. 81, N.S. Stoloff, C.C. Koch, C.T. Liu, and 0. Izumi, eds., pp. 499-506, Materials Research Society, Pittsburgh, PA, 1986.

2. D.J. Gaydosh and M.V. Nathal: NASA TM-87290, 1986.

3. J.L. Smialek, J. Doychak, and D.J. Gaydosh: submitted to Oxid. Met. 1988.

4. C. Barrett: Oxid. Met., 1988, in press.

5. A.G. Rozner and R.J. Wasilewski: J. Inst. Met., 1966, Vol. 94, pp. $169-175$.

6. A. Ball and R.E. Smallman: Acta Met., 1966, Vol. 14, pp. 1349-1355.

7. R.T. Pascoe and C.W.A. Newey: Met. Sci. J., 1968, Vol. 2, pp. 138-143.

8. E.M. Schulson and D.R. Barker: Scr. Metall., 1983, Vol. 17, pp. 519-522.

9. J.D. Whittenberger: J. Mater. Sci., 1988, Vol. 23, pp. 235-240.

10. I.E. Locci and M.V. Nathal: Proc. 45th Meeting of EMSA, G.W. Bailey, ed., pp. 212-213, San Francisco Press, San Francisco, CA, 1987.

11. R.S. Polvani, W.S. Tzeng, and P.R. Strutt: Metall. Trans. A, 1976, Vol. 7, pp. 33-40.

12. J.L. Walter and H.E. Cline: Met. Trans., 1970, Vol. 1, pp. 1221-1229.

13. C.T. Liu: Micon 86: Optimization of Processing, Properties and Service Performance Through Microstructural Control, ASTM STP-979, B.L. Bramfitt, R.C. Benn, C.R. Brinkman, and G.F. Vander Voort, eds., pp. 222-237, ASTM, Philadelphia, PA, 1988.

14. H.A. Lipsitt: in High Temperature Ordered Intermetallic Alloys, MRS Proc. Vol. 39, C.C. Koch, C.T. Liu, and N.S. Stoloff, eds., pp. 351-364, Materials Research Society, Pittsburgh, PA, 1984.

15. C.F. Yolton, T. Lizzi, V.K. Chandhok, and J.H. Moll: in Titanium, Rapid Solidification Technology, T.H. Froes and D. Eylon, eds., pp. 263-272, TMS-AIME, Warrendale, PA, 1986.

16. S.M.L. Sastry and H.A. Lipsitt: in Titanium '80, Science and Technology, H. Kimura and O. Ozumi, eds., pp. 1231-1243, TMS-AIME, Warrendale, PA, 1980.

17. High Temperature, High Strength Nickel Base Alloys, International Nickel Company, Saddle Brook, N.J., 1984.

18. T.E. Strangman, B. Heath, and M. Fuji i: NASA CR-168218, 1983.

19. D.L. McDanels and J.R. Stephens: NASA TM-100844, 1988.

20. D.W. Petrasek and R.H. Titran: DOE/NASA/16310-5, NASA TM-100804, 1988. 
21. P.K. Brindley: in High Temperature Ordered Intermetallic Alloys II, MRS Proc. Vol. 81, N.S. Stoloff, C.C. Koch, C.T. LiU, and 0. Izumi, eds., pp. 419-424, Materials Research Society, Pittsburgh, PA, 1987.

22. P.K. Brindley: "High Temperature Behavior of a $\mathrm{SiC} / \mathrm{Ti}_{3} \mathrm{Al}+\mathrm{Nb}$ Composite," Presented at AIME Annual Meeting, Jan. 1988, Phoenix, AZ.

23. J.A. DiCarlo: J.Mater. Sci., 1986, Vol. 21, pp. 217-224.

24. P.W. Angel, R. Hann, P.K. Brindley: unpublished paper, NASA Lewis Research Center, Cleveland, $\mathrm{OH}$.

25. R.W. Clark and J.D. Whittenberger: in Thermal Expansion 8, Thomas A. Hahn, ed., pp. 189-196, Plenum Press, NY, 1984.

26. P. Shaffer, Handbook of High Temperature Materials, Plenum Press, New York, 1963, p. 316.

27. New Technology in Japan, Vol. 15, No. 6, Sept. 1987. (Japan External Trade Organization (JETRO), New York, NY).

28. R.K. Viswanadham and J.D. Whittenberger: "Elevated-Temperature/ Slow - Plastic Deformation of $\mathrm{NiAl}_{1} / \mathrm{TiB}_{2}$ Composites, "Presented at the Materials Research Society 1988 Spring Meeting, Reno, NV, Apr. 1988.

29. R.A. Perkins: "Oxidation of Refractory Metals," Presented at the Materials Research Society 1988 Spring Meeting, Reno, NV, Apr. 1988.

30. J.R. Stephens and J.K. Tien: NASA TM-83395, 1983.

31. B.A. Ewing and S.K. Jain: "Development of Inconel Alloy MA6000 Turbine Blades for Advanced Gas Turbine Engine Designs," to be presented at the Sixth International Symposium on Superalloys, Champion, PA, Sept. 18-22, 1988. 


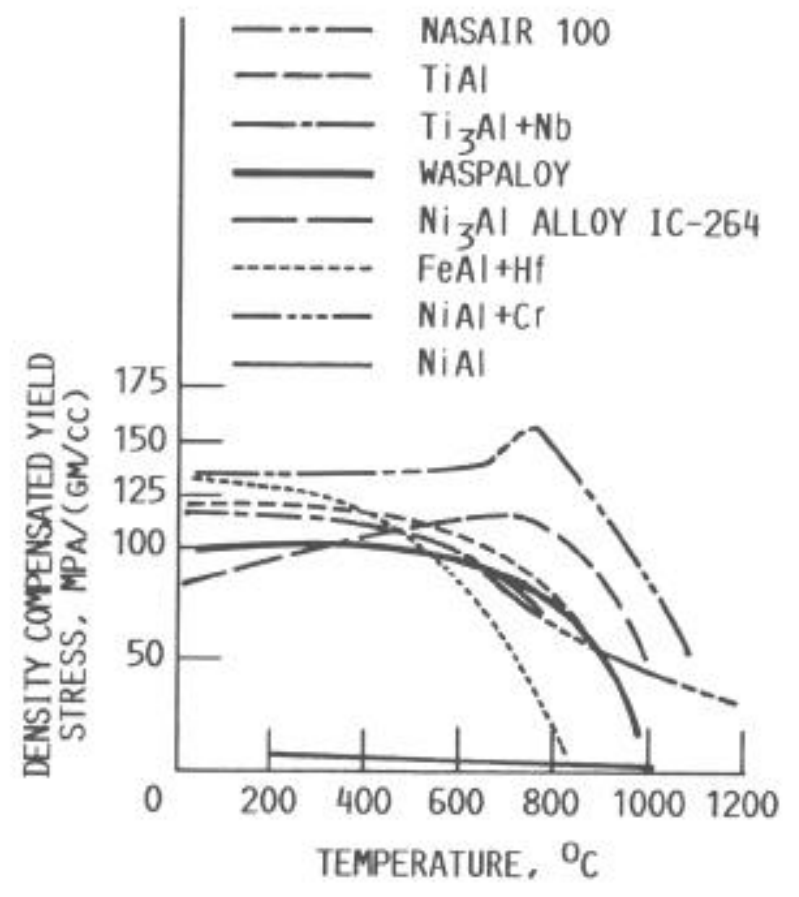

FIGURE 1. - TEMPERATURE DEPENDENCE OF DENSITY COMPENSATED YIELD STRESS FOR SEVERAL INTERMETALLIC ALLOYS AND SUPERALLOYS. DATA IS PRESENTED FOR NIAI (7), Fe-40\% AI-1\%Hf (2), Ni 3 Al ALLOY IC-264 (13), Ti-14\%AI-21\%Nb (15), TiAl (16), DIRECTIONALLY SOLIDIFIED EUTECTIC NiAI+34\%Cr (12), WASPALOY (17), AND SINGLE CRYSTAL NASAIR 100 (18).

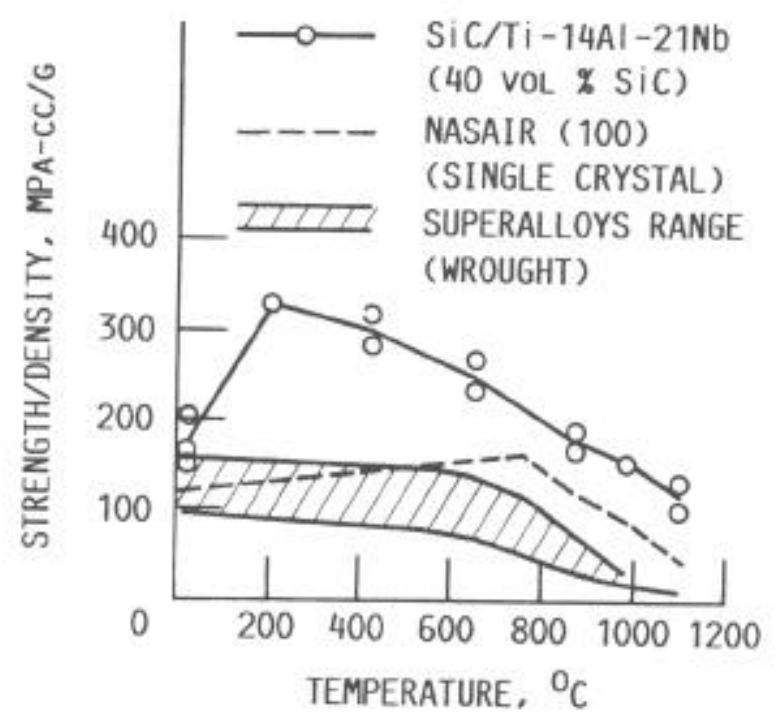

FIGURE 2. - TENSILE BEHAVIOR OF A SiC/Ti 3 AI + Nb COMPOSITE COMPARED TO SUPERALLOYS.

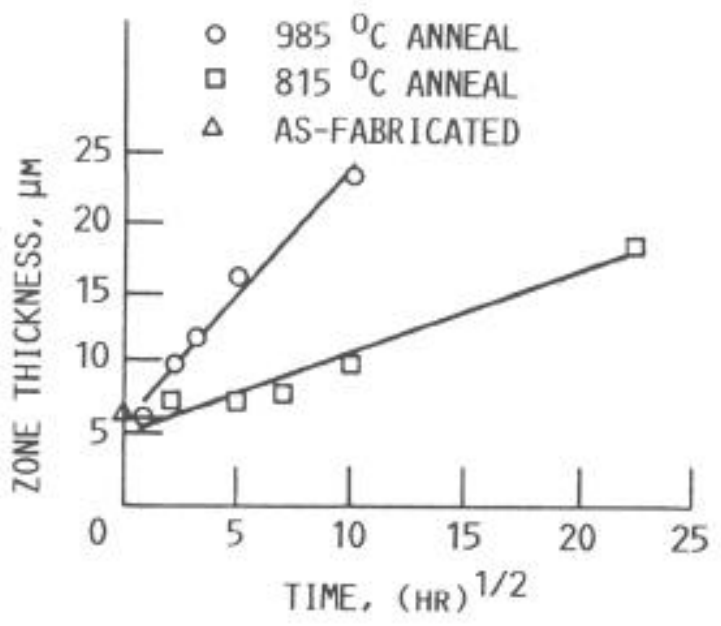

FIGURE 3. - EXTENT OF INTERDIFFUSION BETWEEN FIBER AND MATRIX UPON HIGH TEMPERATURE EXPOSURE.

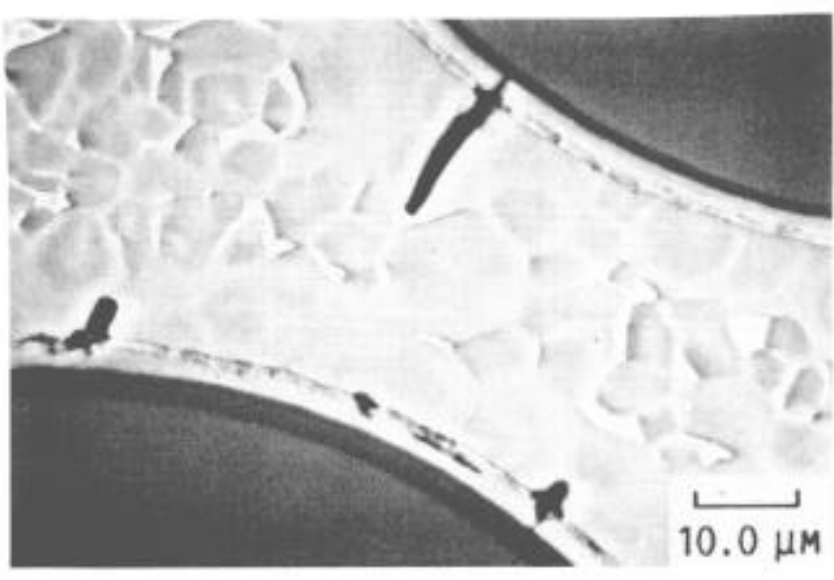

FIGURE 4. - REACTION ZONES, MATRIX DEPLETION, AND CRACKS DEVELOPED IN $\mathrm{SiC} / \mathrm{Ti}_{3} \mathrm{AI}+\mathrm{Nb}$ COMPOSITE AFTER CYCLIC EXPOSURE AT $985{ }^{\circ} \mathrm{C}$. 


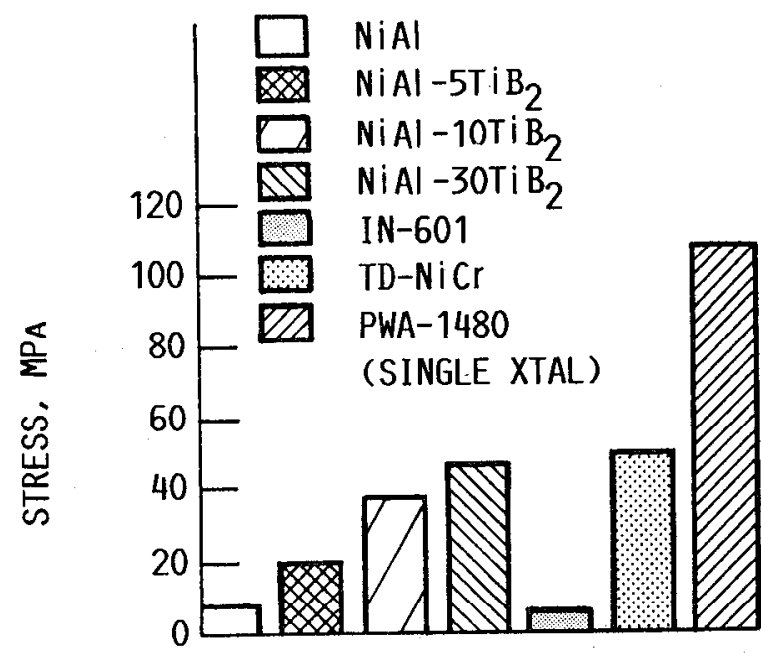

FIGURE 5. - STRENGTH PROPERTIES OF NiAI-TiB 2 PARTICULATE COMPOSITE.

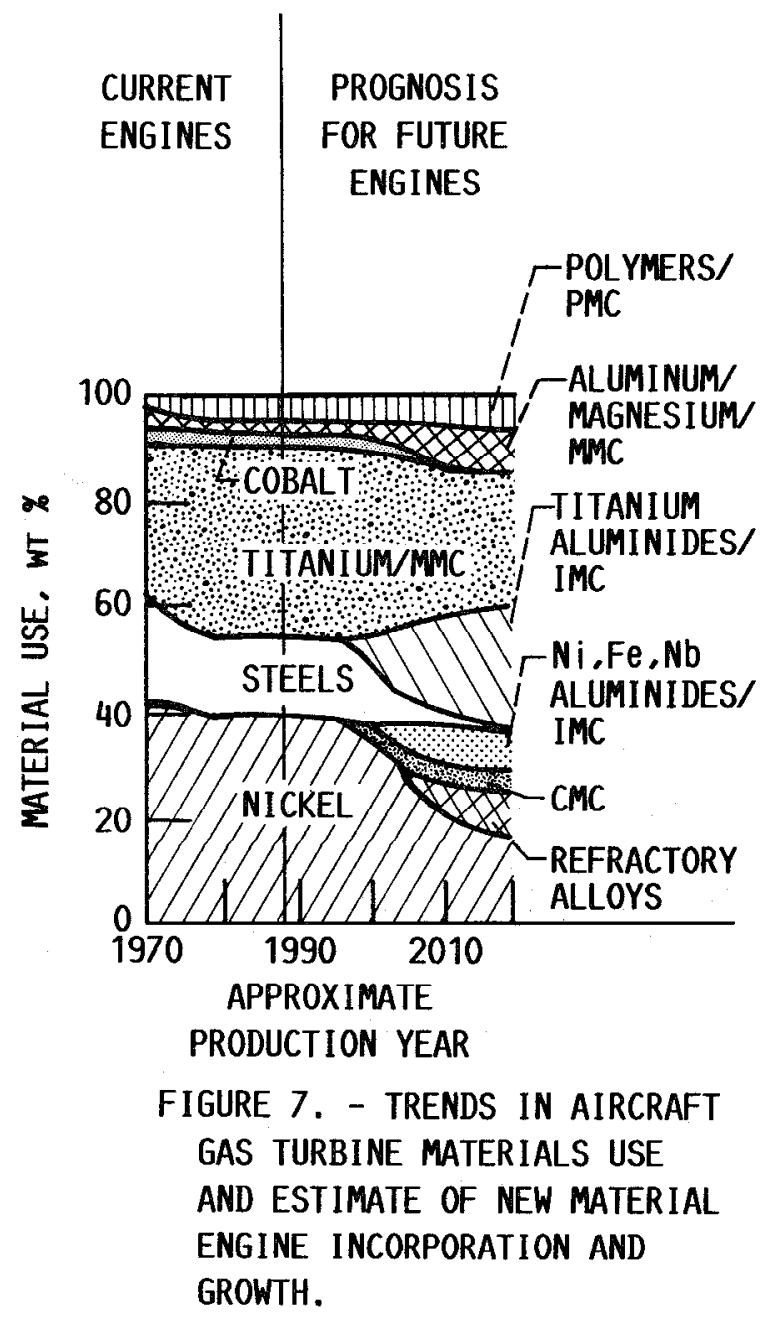

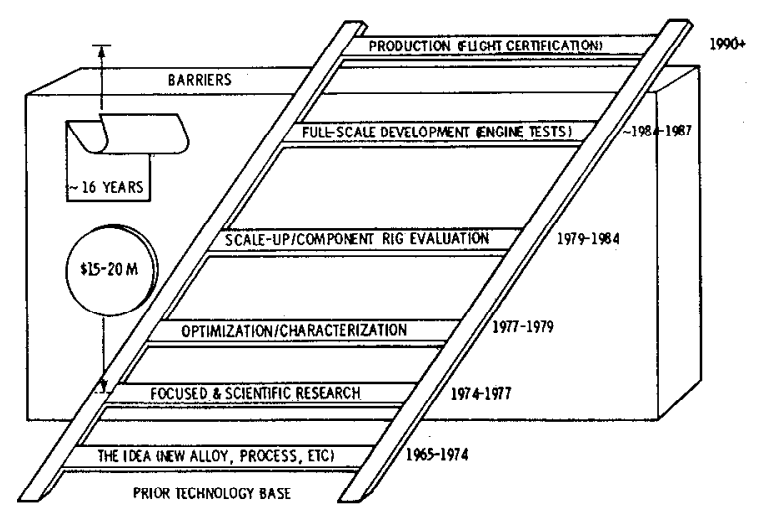

FIGURE 6. - TECHNOLOGY TRANSFER LADDER TO OVERCOME BARRIERS TO INTRODUCTION OF A NEW MATERIAL INTO AIRCRAFT ENGINES, USING THE OXIDE DISPERSION STRENGTHENED ALLOY. MA 6000 AS AN EXAMPLE. 